\title{
A preliminary analysis of water chemistry of the Mkuze Wetland System, KwaZulu-Natal: A mass balance approach
}

\author{
K Barnes ${ }^{1 *}$, W Ellery ${ }^{1}$ and A Kindness ${ }^{2}$ \\ ${ }^{1}$ School of Life and Environmental Sciences, University of Natal, Durban 4041, South Africa \\ 2 School of Pure and Applied Chemistry, University of Natal, Durban 4041, South Africa
}

\begin{abstract}
The Mkuze Wetland System in northern KwaZulu-Natal constitutes an important source of freshwater to Lake St Lucia. The St Lucia System, including both the Mkuze Wetland System and Lake St Lucia, is recognised as a Wetland of International Importance under the Ramsar Convention. The long-term survival of Lake St Lucia depends on an adequate supply of freshwater. Consequently, the role of the Mkuze Wetland System in water quality enhancement is essential.

In order to investigate the water chemistry of this system, water samples were collected throughout the study area from surface water, groundwater, pan and reed swamp sites, as well as a rainwater sample. These were analysed for chloride, sodium, potassium, calcium, magnesium, iron and silicon. Four main water bodies were identified using the multivariate techniques, classification and ordination. Of these four groups, two represented the major water sources to the system, these being the Mkuze River and floodplain and the Mbazwane System. The third represented outflow into Lake St Lucia, while the fourth represented scattered ground and surface water samples some distance away from the main watercourses

The solute concentrations of the two water sources were compared using a mass-balance approach. Chloride was identified as a conserved solute and the increasing chloride concentration from the less concentrated inflows (especially the Mbazwane System) to the concentrated outflow into Lake St Lucia, is considered to reflect evapotranspiration. By considering chloride to be conserved, the degree of evaporative enrichment was estimated in the Mkuze Wetland System and used to determine the percentage of solutes retained in the swamp. The wetland was found to be an important sink for calcium ( $\sim 50 \%$ retention), potassium ( $\sim 0 \%$ retention) and silicon ( $\sim 80 \%$ retention), with magnesium and sodium being retained to a lesser extent. The TDS value supports these findings as it is lower than expected in the outflow by a similar percentage to the magnesium and sodium retention. The removal of solutes by the Mkuze Wetland System, not only has far-reaching implications for Lake St Lucia in maintaining a freshwater supply, but could also have significant impacts on the ecology and geomorphology of the Mkuze System itself. The fate of solutes and the processes of solute retention are subjects of ongoing research.
\end{abstract}

\section{Introduction}

Wetlands occupy positions within the landscape that are transitional between terrestrial and aquatic systems. They are habitats where the water table is at or near the land surface, or where the land is covered by shallow water for a sufficient length of time to cause anaerobic conditions within the root zone of plants (Cowardin et al., 1979). As such they are dominated by hydrophytes.

Despite their position within the landscape, wetlands exhibit features that one would not expect along a gradient from terrestrial to aquatic. This is particularly true with respect to biogeochemical processes. Terrestrial habitats are typically sources of solutes in runoff that drains catchments, whereas aquatic ecosystems are either transporters (rivers) or sinks (lakes and oceans) of such solutes. Wetlands are viewed as sources, sinks or transformers of dissolved solutes within the landscape (Mitsch and Gosselink, 1993), features that are not predictable based simply on their position in the landscape. The source, sink or transformer status of wetlands depends on the type of wetland and its landscape position. For example endorheic pans would be solute sinks, having no surface or subsurface outlet, while peatlands are more likely to function as transformers with inorganic nutrients being incorporated into organic compounds (Mitsch and Gosselink, 1993).

Primary productivity is clearly related to water availability, so one might expect increased productivity on a scale from terrestrial

\footnotetext{
* To whom all correspondence should be addressed.

孟(031) 260-2416; fax: (031) 260-1391; e-mail:961055623@nu.ac.za

Received 20 November 2000; accepted in revised form 16 October 2001.
}

to wetland to aquatic ecosystems. Thus, it is surprising that wetalnds are amongst the most productive habitats on earth. This high biological productivity may contribute in important ways to the ability of wetlands to act as chemical sources, sinks or transformers, since plant biomass and resulting peat deposits may act as chemical sinks (Moore and Bellamy, 1974). In addition, high transpiration rates, and particularly the high ratio of transpiration to evaporation, due to a high degree of plant cover, within wetlands may lead to the accumulation of solutes in wetland soils (McCarthy and Ellery, 1995). During transpiration the plants selectively exclude solutes from the water drawn up by their roots, allowing solutes to concentrate in the groundwater. Under the influence of this concentration mechanism, solutes will reach saturation point at a degree of concentration depending on their chemical nature. Thereafter, compounds will be precipitated, and will accumulate in the soil.

A mass-balance approach is useful in examining the extent to which a wetland acts as a source or sink of dissolved solutes. Such an approach requires comparison of long-term solute inputs and outputs. In situations where inputs are greater than outputs, the wetland would act as a sink, but where inputs are less than outputs, the wetland would be a source. Transformation refers to alteration of solute chemical form (the state in which the solute is transported) from inflow to outflow waters, without changing the total solute mass that entered the system.

In general, wetlands are viewed as sinks for plant macronutrients such as nitrogen and phosphorus (Mitsch and Gosselink, 1993), forming the basis of the widespread use of wetlands for wastewater treatment (Rogers et al., 1985). There is vast and growing literature 


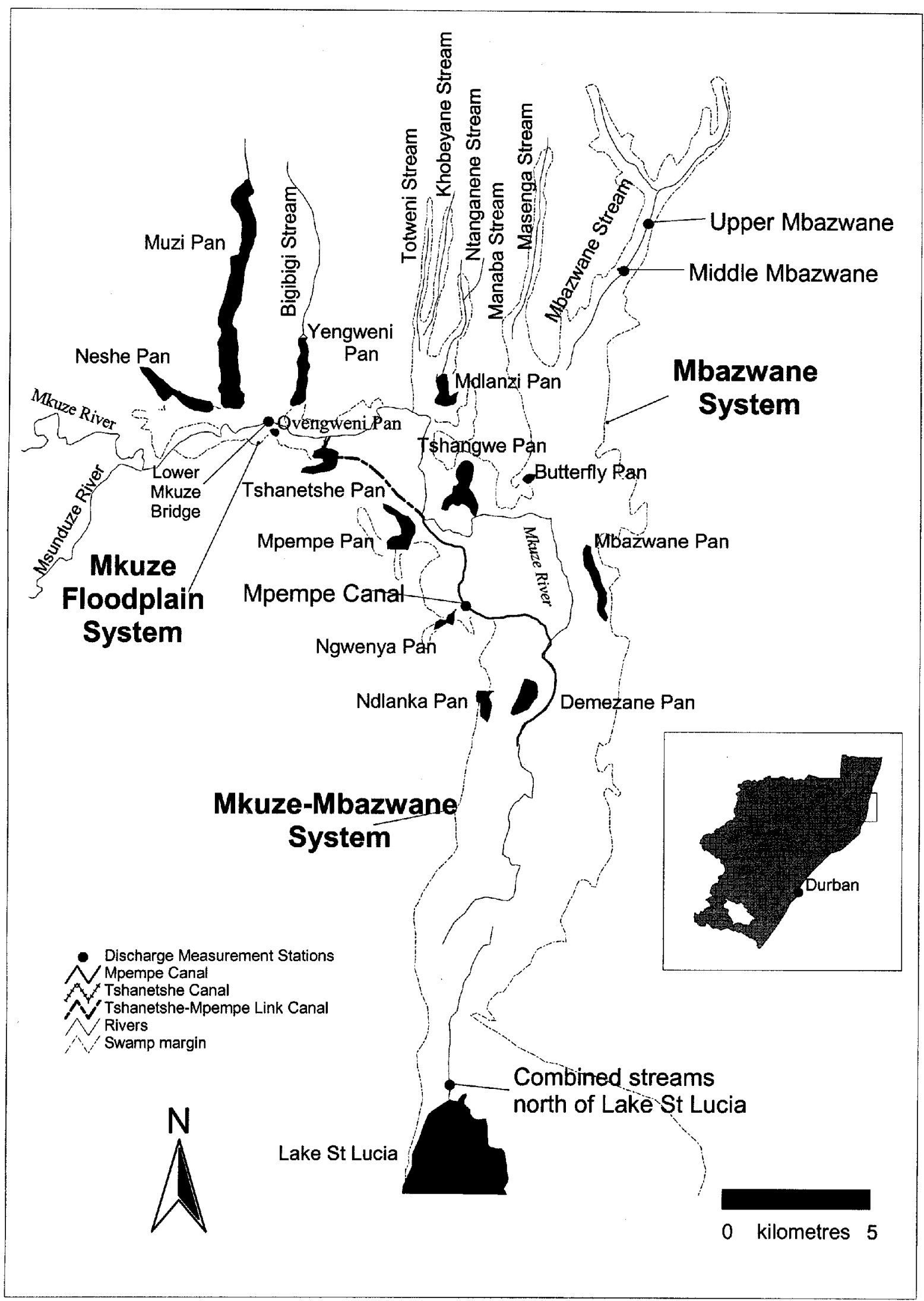

Figure 1

Map of the Mkuze Wetland System indicating the discharge measurement stations 
in these fields (MacKay, 2000). However, the importance of wetlands as sinks for solutes other than plant macronutrients has not received nearly as much attention. Wetland plants and, ultimately, peat deposits are recognised as a sink for many metals (Moore and Bellamy, 1974; McCarthy et al., 1989; Fischer, 2000). Studies in the Okavango Delta, Botswana, have illustrated the importance of transpiration in the permanent and seasonal swamp floodplains and islands in removing calcium, magnesium, silica and sodium from surface waters (McCarthy and Metcalfe, 1990; McCarthy and Ellery, 1995). The importance of these processes for the structure and functioning of the Okavango ecosystem is profound in that surface waters remain remarkably fresh in spite of being subjected to the harsh climate of the Kalahari Desert. In this setting one would expect a shallow saline lake since approximately $98 \%$ of the total water input is lost to the atmosphere as evapotranspiration (Wilson and Dincer, 1976; Gieske, 1996).

System-level studies in which the importance of wetlands as sources, sinks or transformers of dissolved solutes is evaluated are uncommon, particularly in the Southern African Region (Rogers, 1997). Such studies are important in demonstrating the value of wetlands in water quality enhancement (Kotze and Breen, 1994). This accepted indirect value of wetland systems is of potentially great importance in the Mkuze Wetland System for a number of reasons. The Mkuze Wetland System in northern KwaZulu-Natal, is one of South Africa's largest wetlands, and outflow from this wetland constitutes an important source of freshwater to Lake St Lucia, since it is the largest river flowing into the Lake (Stormanns, 1987). Both the Mkuze Wetland System and Lake St Lucia are protected as a Wetland of International Importance in terms of the Ramsar Convention (Cowan, 1995). Furthermore, St Lucia and the surrounding region, including the Mkuze Wetland System, has recently been proclaimed a World Heritage Site and legislation has been promulgated (June 2000) to ensure that the Greater St Lucia Wetland Park is afforded adequate protection (RSA Government Gazette, 1999 and 2000).

Ecosystems such as Lake St Lucia require an adequate input of freshwater for their long-term survival (Taylor, 1993), and it is essential that the role of the Mkuze Wetland System in solute removal be understood if the lake itself is to be protected adequately. This study, therefore, represents a preliminary attempt to document the importance of the Mkuze Wetland System as a solute source, sink, or transformer within the largest fluvial catchment of Lake St Lucia.

\section{Study area}

The Mkuze Wetland System covers an area of approximately 42000 ha, being situated on the Zululand Coastal Plain in northern KwaZulu-Natal (Stormanns, 1987; Begg, 1989). The wetland system comprises a range of wetland types from seasonal to permanent swamps associated with the Mkuze River and the Mbazwane Stream, which converge and drain into Lake St Lucia (Begg, 1989; McCarthy and Hancox, 2000).

The catchment of the Mkuze River occurs mainly on rocks of the Karoo Sequence, comprising the lower stratigraphic units of the Ecca and Lebombo Groups. The Ecca Group, which occurs west of the Lebombo Mountains, comprises sandstones, siltstones and shales of the Vryheid Formation. In the vicinity of the Lebombo range, volcanic rocks, namely basalt and rhyolite of the Letaba and Jozini Formations respectively, are widespread. East of the Lebombo mountains are sedimentary deposits of the Zululand Group, which are overlain by marine deposits of argillaceous sand of the Muzi Formation. More recent deposits overlie the Muzi Formation, these being light-coloured wind-blown sands, as well as recent alluvial deposits of the Mkuze River floodplain and the Mbazwane Stream.

The region of the Mkuze Wetland System has hot, wet summers and mild, dry winters, with a mean annual temperature of 21 to $23^{\circ} \mathrm{C}$. The area experiences summer rainfall of between 1000 to 1 $100 \mathrm{~mm} \cdot \mathrm{a}^{-1}$ at the coast to only $600 \mathrm{~mm} \cdot \mathrm{a}^{-1}$ at the base of the Lebombo Range (Maud, 1980). The prevailing winds are northeasterly and south-westerly (Watkeys et al., 1993).

The Mkuze Wetland System is fed by two major surface hydrological inputs, the Mkuze River from the west and the six southward flowing "Manzibomvu Streams" that drain the unconsolidated sandy coastal plain to the north of the Mkuze River. This includes the Mbazwane Stream, the Masenga Stream and those southward flowing streams that drain into the Mdlanzi Pan (Fig. 1). Mean annual flow in the Mkuze River varies between 211 and $326 \times 10^{6} \mathrm{~m}^{3}$ (Hutchinson and Pitman, 1973), with seasonal flooding in summer and little or no flow in winter. Extreme flooding events are not uncommon, being associated with cut-off lows moving up the coast from the south-west and occasionally with tropical cyclones (Watkeys et al., 1993). Discharge typically declines downstream (McCarthy and Hancox, 2000), as water is lost continually from the river.

Mkuze River water is characterised by a relatively high suspended sediment load of silt and clay entering the Mkuze Wetland System from the Mkuze River catchment (McCarthy and Hancox, 2000) and a comparatively high conductivity at 0.843 to $1.160 \mathrm{mS} \cdot \mathrm{cm}^{-1}$ (Stormanns, 1987). In contrast, the Mbazwane Stream seldom floods, conductivity is low at approximately 0.310 $\mathrm{mS} \cdot \mathrm{cm}^{-1}$, the water is free of suspended clastic sediment and discharge increases downstream due to continual groundwater input (Stormanns, 1987).

The Mkuze River is split along its course by a canal that was excavated in the late 1960 s by the Natal Provincial Administration Reclamation Unit in order to increase the supply of freshwater to Lake St Lucia (Goodman, 1987). At the time, the lake was experiencing hypersaline conditions as a result of a regional drought. This canal is known as the Mpempe Canal (Fig. 1). An additional canal was excavated between the Mkuze River and the Tshanetshe Pan by a private landowner in order to provide permanent surface water for livestock (Goodman, 1987). This is known as the Tshanetshe Canal. The watercourse between the Mpempe and Tshanetshe Canals has eroded naturally as a consequence of the excavation of these two canals, and for the purposes of this study will be referred to as the Tshanetshe-Mpempe Link Canal. The combined canals draw off most of the water, leaving the former Mkuze River channel downstream of the Tshanetshe offtake with a substantially reduced water supply ( $80 \%$ reduction; Goodman, 1987).

The Mkuze Wetland System is situated in a vegetation type known as Coastal Bushveld-Grassland (Granger et al., 1996). The vegetation comprises a mosaic of forest patches set in a matrix of grassland and open savanna. In northern KwaZulu-Natal, the vegetation type is characterised by grassland with scattered clumps of palms (Hyphaene natalensis), while in many areas it consists of grassland with scattered dwarf shrubs.

The wetland supports a wide range of plant communities including hygrophilous grassland, sedge marsh, sedge and reed swamp, floodplain forest, riparian forest, swamp forest and palmveld (Stormanns, 1987). Approximately 275 plant species are found in the wetland system, which supports at least 32 rare and endangered species (Stormanns, 1987). 


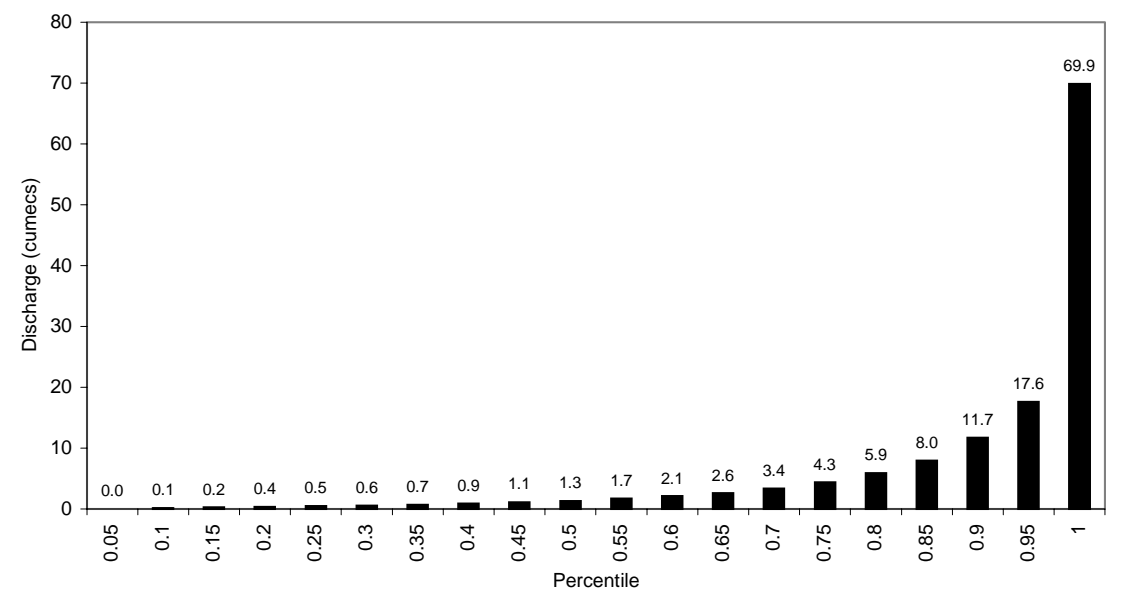

Figure 2

Frequency distribution of discharge values at the Lower Mkuze Bridge, 10/1970-09/1987. Data supplied by the Department of Water Affairs

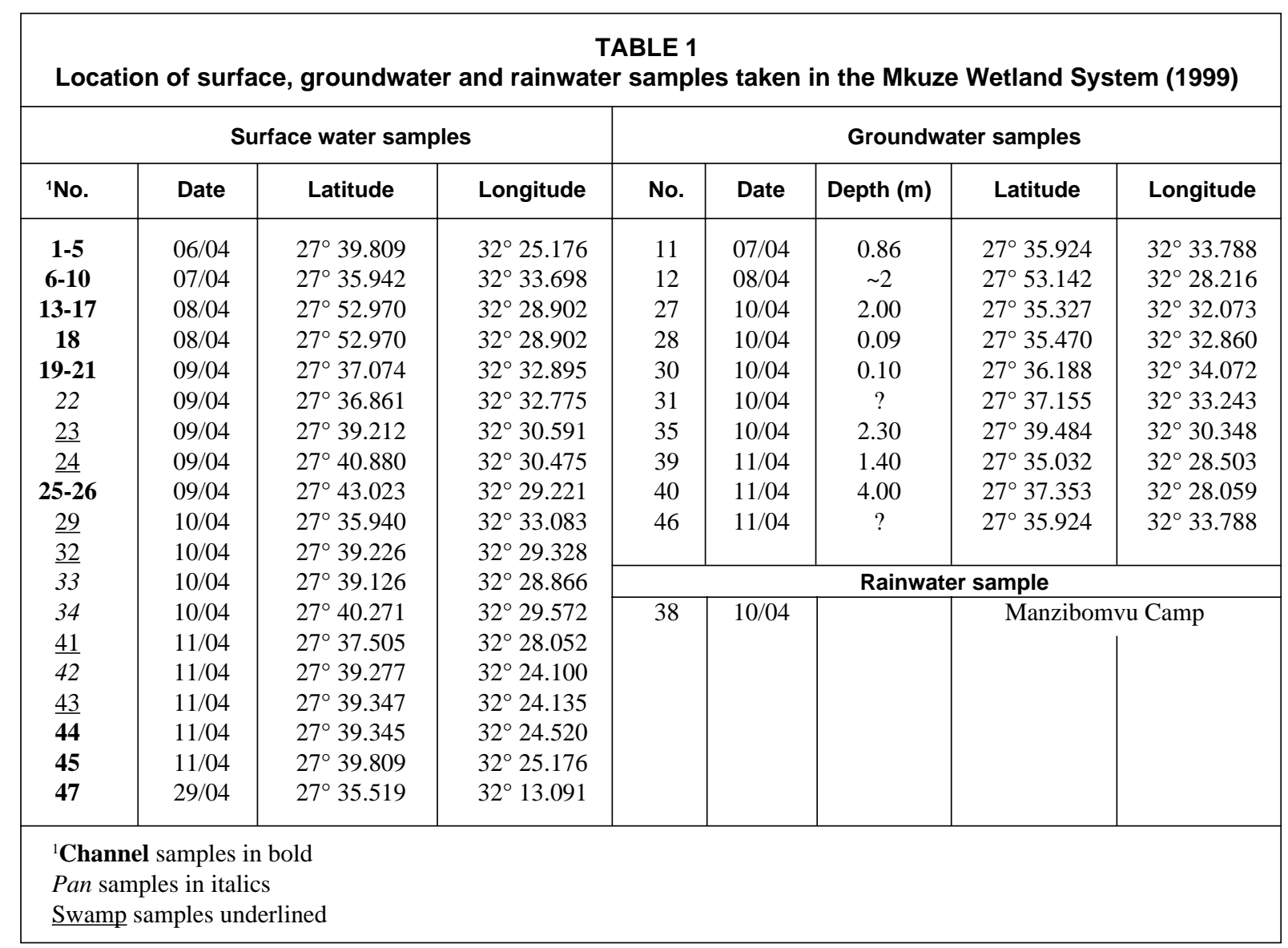

\section{Methods}

Water samples were collected throughout the Mkuze Wetland System for a week in April 1999, using the grab method of sampling. The intention was to obtain data over as short a time period as possible so that surface and groundwater conditions were constant. In this way, dilution as a result of a large rainfall event would be minimal as would concentration in the absence of rainfall. Furthermore, discharges close to the median were desirable, since this represents "typical" flow conditions, and while the sampling period provided discharges slightly higher than this, they were within acceptable limits (Fig. 2).

Sampling was carried out to cover as wide a range of surface and groundwater conditions as possible (Table 1). Particular emphasis was placed on the two main surface water inputs, namely the Mkuze River (including the artificial canals) and the Mbazwane Stream, as well as the combined outflow into Lake St Lucia. In addition, reed swamp-, pan- and groundwater were collected throughout the study area, while one rainwater sample was collected during a heavy shower on the last night of the sampling period, using a funnel attached to a sample bottle. A small number of surface and groundwater samples (40 \& 42-46) was collected following this shower, including the Mkuze River at the Lower Mkuze Bridge, which had been sampled previously. Concentrations of solutes at the bridge following the shower of rain were within 5\% of the concentrations before the shower, suggesting that it had a relatively minor effect. All samples were refrigerated on return to the laboratory in Durban. 
Discharge was measured by determining the channel cross- a sectional profile at each of five stations, followed by current velocity measurement using a Marsh McBirney Modle 201 portable current meter at three depths at five or more intervals across the channel. Discharge was calculated from these data by the velocityarea method (Gordon et al., 1992). Measurements were made on the Mkuze River at the Lower Mkuze Bridge (Mkuze River inflow), on the Mpempe Canal at Ngwenya Pan, at two sites on the Mbazwane Stream (Mbazwane Stream inflow) and at the point of combined river flow north of Lake St Lucia (outflow; Fig. 1).

Groundwater was sampled by augering to the water table and depth to groundwater was measured at all localities where it was sampled. In all cases it was possible to estimate the elevation of the land surface to within a metre, either from orthophotos or by conventional surveying using a dumpy-level and staff. Long-range cross-sectional profiles were constructed using a combination of orthophoto elevations and groundwater depth measurements.

Sample analysis for calcium, iron, magnesium and silicon was conducted by inductively coupled plasma optical emission spectroscopy (ICP-OES). Potassium and sodium concentrations were determined by flame emission spectroscopy, and the chloride concentration by the Volhard titration (Skoog et al., 1996). The RSD's, at less than $10 \%$ for all solutes except iron (40\%) and potassium $(15 \%)$ were considered to be acceptable for our purposes of classifying water samples into homogeneous groups. The high variability of the iron values resulted in their exclusion from the data analysis. Total Dissolved Salts (TDS) was calculated by correcting the measured conductivity values using an empirical conversion factor. This was determined by filtering and evaporating approximately $25 \%$ of the samples covering a wide range of conductivities. The precipitated residue was weighed and regression was used to determine the relationship between conductivity and TDS. Because of the correlation between conductivity and TDS, only TDS was included in the statistical analyses.

The statistical package SPSS was used to run both hierarchical cluster and principal components analyses on the water chemistry data. In both cases, the default settings were applied (SPSS, 1995). The hierarchical cluster analysis, which groups similar cases based on measured variables, provided a preliminary sample grouping in the form of a dendrogram (Mardia et al., 1979). Principal component analysis was employed to obtain a two-dimensional display of the similarity and difference between samples (Mardia et al., 1979). It also allowed identification of those variables that were most useful in classifying water samples into different groups.

\section{Results}

\section{Discharge}

The discharge for each measurement station is shown in Table 2. Inflow to the wetland system from the Mkuze River was approximately $2.4 \mathrm{~m}^{3} \cdot \mathrm{s}^{-1}$, and this declined to $1.4 \mathrm{~m}^{3} \cdot \mathrm{s}^{-1}$ along the Mpempe Canal at Ngwenya Pan. This may be due to flow of water along the Mkuze River downstream of the Tshanetshe Canal offtake, to water loss to the atmosphere by evaporation, to groundwater recharge or a combination of these. Since there are no distributaries and loss to groundwater is likely to be low in view of the clay-rich nature of the floodplain sediments, this decrease in discharge is likely to be due to evaporative concentration causing increased solute concentrations, by a factor of $1.7\left(2.4 \mathrm{~m}^{3} \cdot \mathrm{s}^{-1} /\right.$ $1.4 \mathrm{~m}^{3} \cdot \mathrm{s}^{-1}$ ) in the canal water samples. Inflow to the wetland system from the Mbazwane Stream increased downstream from the upper Mbazwane $\left(0.31 \mathrm{~m}^{3} \cdot \mathrm{s}^{-1}\right)$ to the middle Mbazwane $\left(0.45 \mathrm{~m}^{3} \cdot \mathrm{s}^{-1}\right)$,
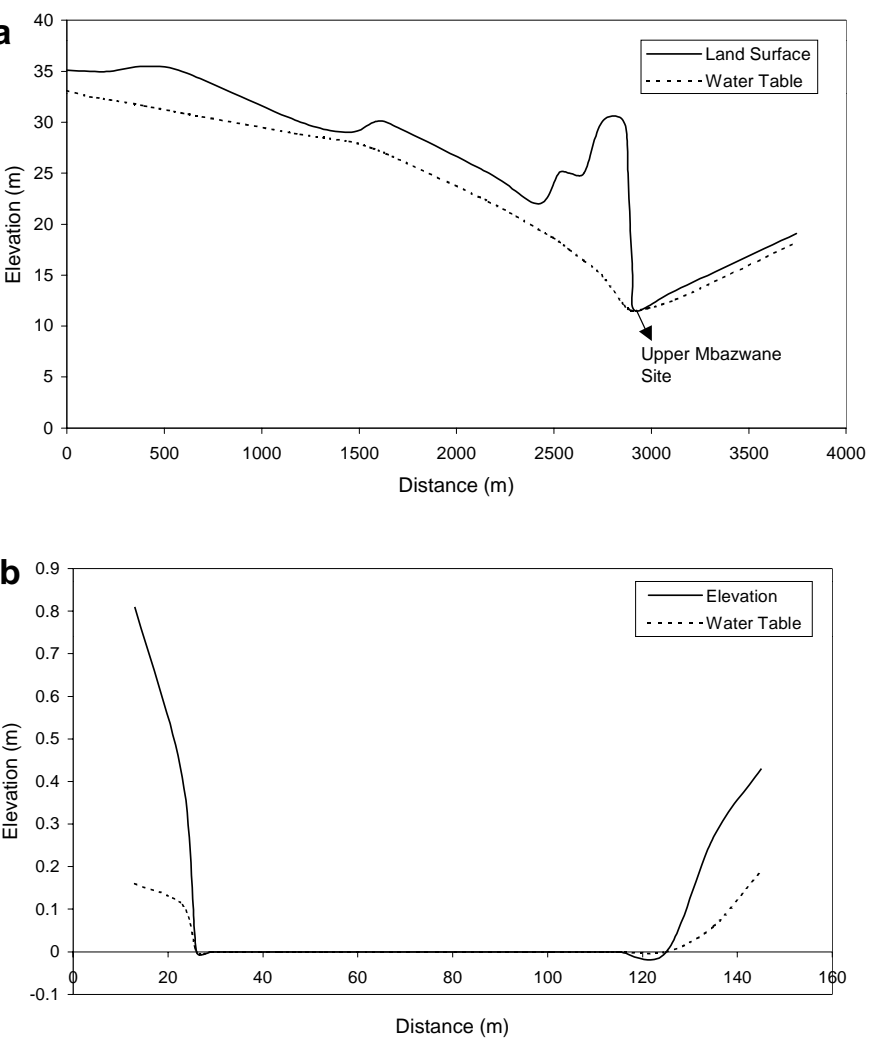

Figure 3

Topographic and water table profiles across the Mbazwane Stream at the upper Mbazwane site (a) and the middle Mbazwane site (b)

suggesting continual groundwater input to this system. This is supported by consideration of the elevation of the groundwater table that slopes towards the Mbazwane Stream at these locations together with the high hydraulic conductivity of the sandy soil which allows for the relatively rapid movement of sub-surface water (Fig. 3). Outflow from the Mkuze Wetland System into Lake St Lucia was $3.4 \mathrm{~m}^{3} \cdot \mathrm{s}^{-1}$, which is greater than the combined flows of the Mkuze River, Mpempe Canal and the Mbazwane Stream, suggesting that there are additional inputs to the system, probably as groundwater inputs along the Mbazwane Stream. Based on mean current velocities in the Mkuze River and in the canal, water would be expected to flow through the system over the period of one day.

\section{Classification of water samples}

The hierarchical cluster analysis distinguishes 8 groups of samples that are considered to represent meaningful sample groupings based on the water chemistry and the locations of sample sites within the study area (Fig. 4). The variables used to define the sample clusters were calcium, chloride, magnesium, potassium, silicon and sodium concentrations, as well as TDS.

Further division of groups below a rescaled distance (a measure of similarity between sample groups) of about 3 is considered insufficient to justify meaningful separation of samples, and the groups described above are considered to represent relatively homogeneous sample groups, for the purposes of this study. 


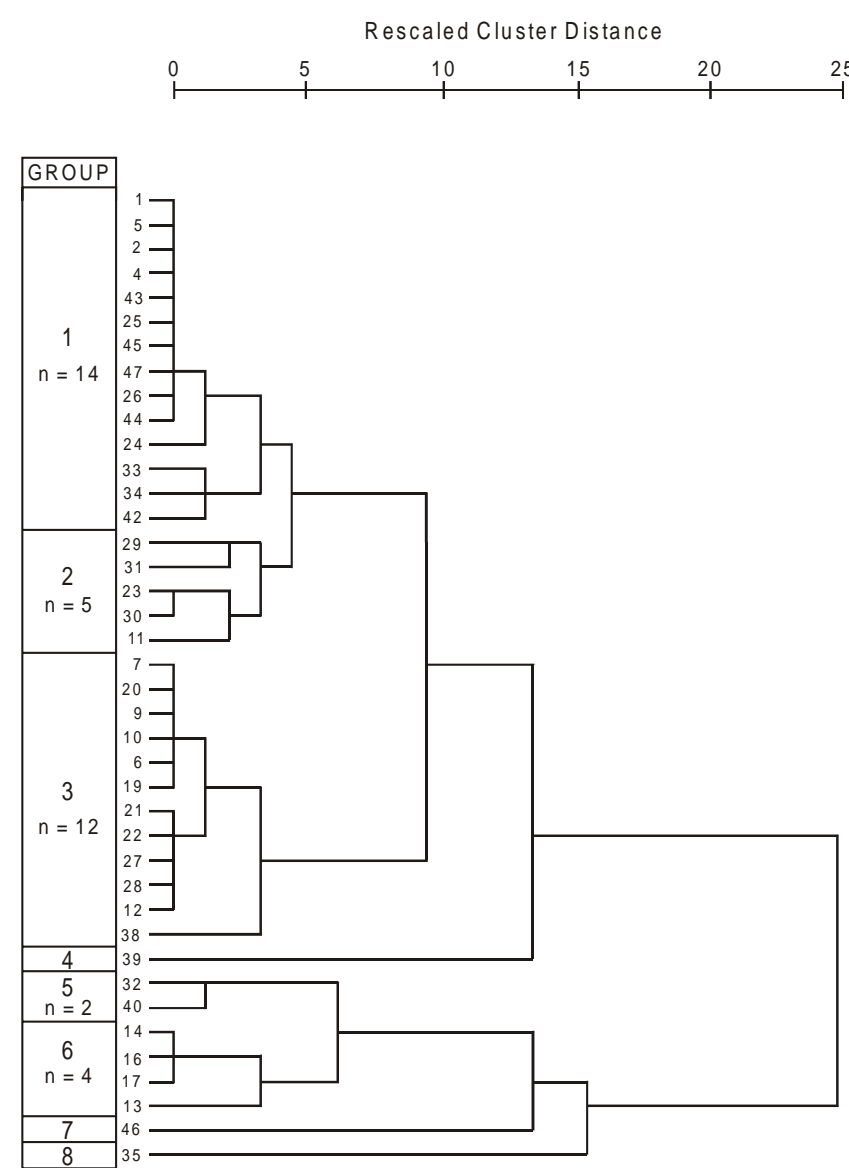

Figure 4

Dendrogram displaying clusters of surface and groundwater samples in the Mkuze Wetland System, as identified by hierarchical cluster analysis

\section{Geographical distribution of sample groupings}

Group 1 consists of surface water samples derived from the Mkuze River and its floodplain, including the Mpempe Canal and a variety of freshwater habitats such as pans and marshes along the floodplain (Table 3). The samples of Group 2 include groundwater to the east of the Mbazwane Stream and reed swamp samples from the west of the stream. Group 2 is most closely linked with Group 1 in the cluster analysis. Samples in Group 3 include surface water of the Mbazwane Stream as well as surface and groundwater samples immediately adjacent to the Mbazwane Stream. Also included in Group 3 is a single groundwater sample in sandy terrain west of the Mkuze-Mbazwane System, near Lake St Lucia. The rainwater sample is least like the other samples in Group 3, but is included at the level of heterogeneity which is considered to be appropriate. A single groundwater sample obtained from the head of the drainage line leading to Mdlanzi Pan, constitutes Group 4. This group is most closely linked with the samples of Group 3, but it was separated from Group 3 at a very high rescaled distance, indicating low similarity. Group 5 consists of a sample obtained below surface from dry papyrus swamp between Mdlanzi and Tshangwe Pans and a groundwater sample west of the Totweni Stream. Group 6 comprises outflow from the Mkuze-Mbazwane System into Lake St Lucia. Groups 7 and 8 each contain one sample, groundwater samples west of the Mpempe Canal and west of the Mbazwane Stream respectively.
TABLE 2

Measured discharge at selected locations within the Mkuze Wetland System

\begin{tabular}{|l|c|}
\hline Station & $\begin{array}{c}\text { Discharge } \\
\left(\mathbf{m}^{\mathbf{3}} \cdot \mathbf{s}^{-1}\right)\end{array}$ \\
\hline Lower Mkuze Bridge & 2.4 \\
Mpempe Canal at Ngwenya Pan & 1.4 \\
Upper Mbazwane Stream & 0.31 \\
Middle Mbazwane Stream & 0.45 \\
Combined streams north of Lake St Lucia & 3.4 \\
\end{tabular}

TABLE 3

Geographic locations represented by Groups 1-8 of the surface and groundwater samples in the Mkuze Wetland System

\begin{tabular}{|c|c|}
\hline Group & Geographic locations \\
\hline 1 & Mkuze River and floodplain \\
\hline 2 & $\begin{array}{l}\text { Groundwater east of Mbazwane Stream and reed } \\
\text { swamp west of the Stream }\end{array}$ \\
\hline 3 & $\begin{array}{l}\text { Mbazwane Stream; surface and groundwater samples } \\
\text { adjacent to the Stream }\end{array}$ \\
\hline 4 & Head of drainage line leading to Mdlanzi Pan \\
\hline 5 & $\begin{array}{l}\text { Papyrus Swamp between Mdlanzi and Tshangwe } \\
\text { Pans; groundwater west of Totweni Stream }\end{array}$ \\
\hline 6 & Outflow of Mkuze Wetland System into Lake St Lucia \\
\hline 7 & Groundwater west of Mpempe Canal \\
\hline 8 & Groundwater west of Mbazwane Stream \\
\hline
\end{tabular}

TABLE 4

Eigenvalues and percentage contribution of each component in the principal components analysis ordination of surface and groundwater samples in the Mkuze Wetland System

\begin{tabular}{|c|c|c|c|}
\hline Dimension & $\begin{array}{c}\text { Eigen } \\
\text { value }\end{array}$ & $\begin{array}{c}\text { Percentage } \\
\text { contribution } \\
(\%)\end{array}$ & $\begin{array}{c}\text { Cumulative } \\
\text { percentage } \\
\text { (\%) }\end{array}$ \\
\hline $\mathbf{1}$ & 0.6038 & 62.8 & 62.8 \\
$\mathbf{2}$ & 0.1472 & 15.3 & 78.1 \\
$\mathbf{3}$ & 0.1309 & 13.6 & 91.7 \\
$\mathbf{4}$ & 0.0800 & 8.3 & 100 \\
\hline
\end{tabular}

The principal component analysis suggests that the first dimension of the ordination is by far the most important as it has a high eigenvalue and accounts for a large proportion $(62.8 \%)$ of the overall variation in the data (Table 4). Dimensions 2 and 3 account for a further $28.9 \%$ of the variation in the data.

The ordination of samples is similar to the classification presented in the cluster analysis as each of the five dominant groups occurs as a relatively well-defined cluster on the first two dimensions of the ordination (Fig. 5). Furthermore, Groups 4, 7 and 8 (each with a single sample) that were identified in the cluster analysis as being 
Figure 5

Diagram showing groupings of surface and groundwater samples in the Mkuze Wetland System, plotted on axis 1 and axis 2 of the principal components analysis ordination. Component loadings are shown for various solutes and TDS

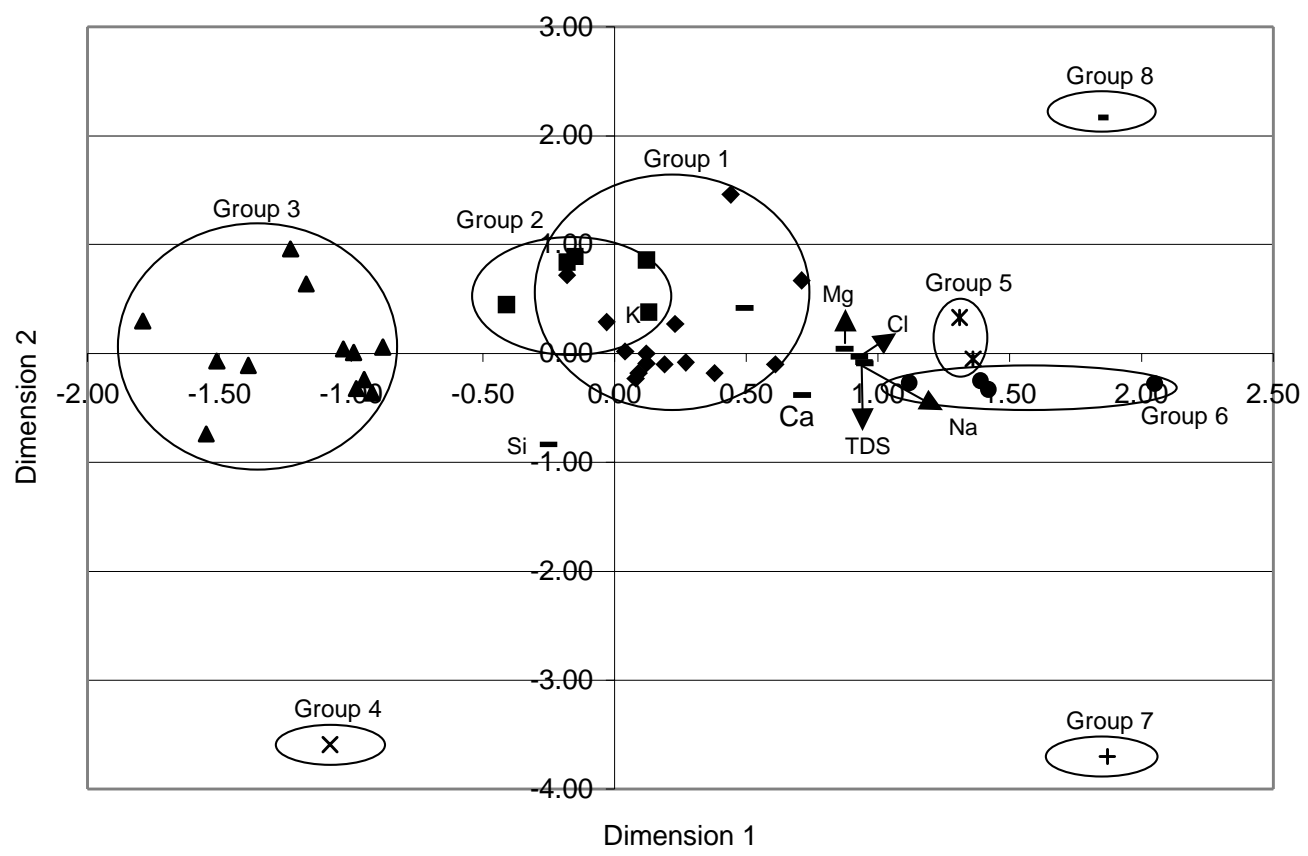

dissimilar from the remaining five dominant groups, are displayed as outliers in the ordination. The ordering of the main groups along dimension one of the ordination is somewhat different from the arrangement of samples in the cluster analysis. The approximate ordering of main groups along the first dimension of the ordination from lowest to highest is Groups $3,2,1,5$ and 6 .

The location of component loadings in the ordination provides an indication of the contribution of these variables to variance in the data. As a whole, chloride, magnesium, sodium and TDS, with high scores on the first dimension, contribute most to the variance along dimension one, and samples in Groups 5 and 6 have high values for these variables. In contrast, Group 3 has low values for these variables. Silicon appears to be the only variable that contributes to variation in the second dimension, with a relatively low score on this dimension.

\section{Characterisation of water chemistry}

The mean concentrations and associated standard deviations of solutes in samples of the five main groups identified in the cluster analysis are shown in Table 5. Groups 1 and 6 have the highest calcium and magnesium concentrations of all groups, whereas Groups 2 and 3 have the lowest. The highest concentrations of chloride, sodium and TDS are associated with Groups 5 and 6, while Group 3 has the lowest concentrations of these solutes. The potassium and silicon concentrations are similar in all groups.

Based on the classification, ordination and the distribution of water samples in relation to regional hydrology, it is possible to identify four distinct groups of samples. Group 1 represents water

\section{TABLE 5}

Mean solute concentrations and standard deviations for the five main System, as identified by hierarchical cluster analysis

\begin{tabular}{|c|c|c|c|c|c|c|c|}
\hline $\begin{array}{l}\text { Group in } \\
\text { cluster } \\
\text { analysis }\end{array}$ & $\begin{array}{c}\mathrm{Cl}^{-} \\
(\mathrm{ppm})\end{array}$ & $\begin{array}{c}\mathrm{Na}^{+} \\
(\mathrm{ppm})\end{array}$ & $\begin{array}{c}\mathbf{K}^{+} \\
(\mathbf{p p m})\end{array}$ & $\begin{array}{c}\mathrm{Ca}^{2+} \\
\text { (ppm) }\end{array}$ & $\begin{array}{c}\mathbf{M g}^{2+} \\
(\mathbf{p p m})\end{array}$ & $\begin{array}{c}\mathrm{Si} \\
(\mathrm{ppm})\end{array}$ & $\begin{array}{c}\text { TDS } \\
\text { (ppm) }\end{array}$ \\
\hline $\begin{array}{c}3 \\
\mathrm{n}=12\end{array}$ & $\begin{array}{c}33.9 \\
(13.8)\end{array}$ & $\begin{array}{c}33.3 \\
(20.4)\end{array}$ & $\begin{array}{c}2.5 \\
(1.2)\end{array}$ & $\begin{array}{l}10.7 \\
(8.2)\end{array}$ & $\begin{array}{c}5.0 \\
(1.8)\end{array}$ & $\begin{array}{c}9.5 \\
(3.6)\end{array}$ & $\begin{array}{c}95.0 \\
(42.9)\end{array}$ \\
\hline $\begin{array}{c}2 \\
n=5\end{array}$ & $\begin{array}{c}137.8 \\
(34.9)\end{array}$ & $\begin{array}{c}91.6 \\
(12.2)\end{array}$ & $\begin{array}{c}6.5 \\
(4.5)\end{array}$ & $\begin{array}{l}12.1 \\
(5.6)\end{array}$ & $\begin{array}{l}15.8 \\
(7.4)\end{array}$ & $\begin{array}{c}7.3 \\
(2.8)\end{array}$ & $\begin{array}{l}271.8 \\
(47.1)\end{array}$ \\
\hline $\begin{array}{c}1 \\
\mathrm{n}=14\end{array}$ & $\begin{array}{c}91.7 \\
(21.8)\end{array}$ & $\begin{array}{c}102.2 \\
(11.6)\end{array}$ & $\begin{array}{c}5.5 \\
(3.9)\end{array}$ & $\begin{array}{l}34.5 \\
(5.5)\end{array}$ & $\begin{array}{l}31.9 \\
(4.3)\end{array}$ & $\begin{array}{c}6.8 \\
(1.3)\end{array}$ & $\begin{array}{l}272.7 \\
(35.9)\end{array}$ \\
\hline $\begin{array}{c}5 \\
n=2\end{array}$ & $\begin{array}{l}251.9 \\
(40.1)\end{array}$ & $\begin{array}{l}237.5 \\
(38.9)\end{array}$ & $\begin{array}{c}7.3 \\
(1.3)\end{array}$ & $\begin{array}{l}19.8 \\
(6.3)\end{array}$ & $\begin{array}{l}23.0 \\
(0.5)\end{array}$ & $\begin{array}{c}7.5 \\
(0.7)\end{array}$ & $\begin{array}{c}548.0 \\
(7.1)\end{array}$ \\
\hline $\begin{array}{c}6 \\
n=4\end{array}$ & $\begin{array}{l}229.7 \\
(42.2)\end{array}$ & $\begin{array}{l}188.3 \\
(26.3)\end{array}$ & $\begin{array}{c}4.8 \\
(0.9)\end{array}$ & $\begin{array}{l}37.6 \\
(1.1)\end{array}$ & $\begin{array}{l}46.0 \\
(3.7)\end{array}$ & $\begin{array}{c}8.1 \\
(0.2)\end{array}$ & $\begin{array}{l}514.8 \\
(73.5)\end{array}$ \\
\hline
\end{tabular}

Note: Standard deviations appear in brackets flowing into the system from the catchment of the Mkuze River to the west. Groups 2 and 3 represent water flowing into the system from the north via the Mbazwane Stream. The third group (Group 6) represents water flowing from the Mkuze Wetland System (combined Mkuze River and Mbazwane Stream) into Lake St Lucia. A fourth group of samples represents those that are outliers in the ordination $(n=3)$ and those in Group $5(n=2)$ of the classification that were from scattered localities within the system.

It is of interest to consider the concentration of various solutes in relation to conductivity, which is an indication of the concentration of total dissolved salts. One might expect the concentration of 

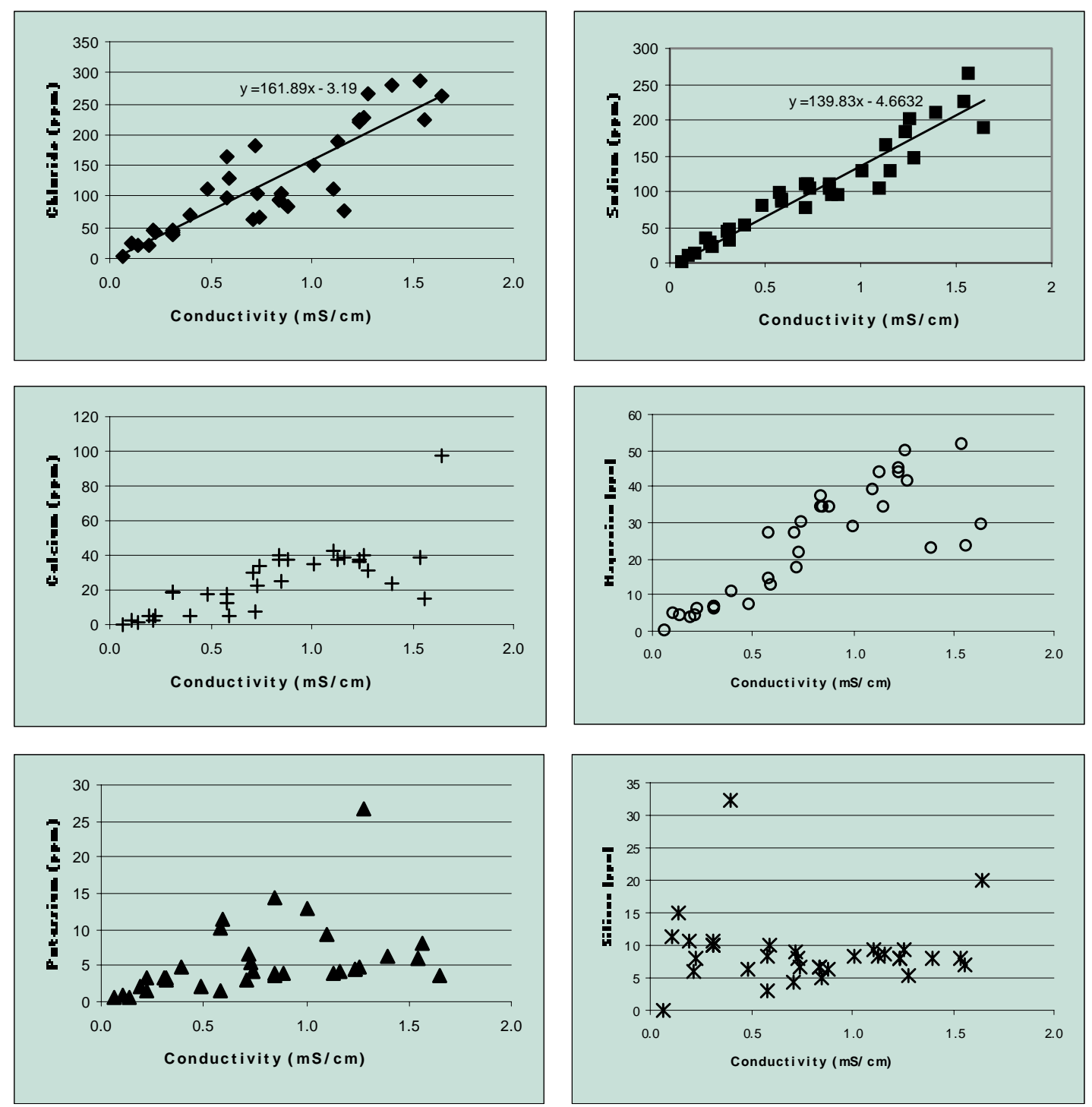

Figure 6

The relationship between solute concentration and conductivity of surface and groundwater samples in the Mkuze Wetland System concerning chloride (a), sodium (b), calcium (c), magnesium (d), potassium (e) and silicon (f)

dissolved salts of a single body of water to vary systematically with evaporation (increased conductivity) or rainfall (decreased conductivity). The concentrations of chloride, sodium, calcium and magnesium increase systematically with an increase in conductivity (Figs. 6a, b, c and d), suggesting enrichment of solutes by the process of evapotranspiration. In all cases, the concentration of these solutes is lowest in the water of the Mbazwane Stream System, higher in the Mkuze River and its associated floodplain, wetlands and pans; and highest in the outflow to Lake St Lucia. The remaining samples also show high conductivity and solute concentrations with the exception of a single sample at the head of the Totweni Drainage Line, which resembles water of the Mbazwane Stream. This is not surprising since it drains similar sandy terrain to that of the Mbazwane Stream. In contrast to this expected pattern of a systematic increase in concentration of individual solutes with increasing conductivity, potassium shows only a weak relationship (Fig. 6e), whereas silicon shows no relationship (possibly a negative relationship) with conductivity (Fig. 6f). This is likely to be a result of silicon being in two forms, both colloidal and dissolved.

\section{Discussion}

\section{The influence of catchment geology and evapo- transpiration on water chemistry}

The Mkuze River drains a catchment mainly of sandstone, siltstone, basalt and rhyolite of the Karoo Sequence in addition to siltstone and sandstone of the Zululand Group. The remainder of the river course crosses alluvial sediments, which are the product of depositional processes of the Mkuze River as its gradient decreases on entering the flat coastal plain east of the Lebombo Mountains. The Mbazwane catchment is situated on reworked marine sands, with low potential to contribute solutes to the wetland system.

The sedimentary siltstones and sandstones of the Mkuze River catchment contribute relatively few dissolved salts on weathering and consist mainly of silica cemented by low concentrations of calcium carbonate and iron oxide (Hamblin, 1992). Basalt and rhyolite, however, are more vulnerable to weathering, the ultimate products of which are clay and iron oxides, producing a red or 
brown sediment (Hamblin, 1992). Basalt consists mainly of calcium plagioclase $\left(\mathrm{CaAl}_{2} \mathrm{Si}_{2} \mathrm{O}_{8}\right)$, pyroxene $\left(\mathrm{MgSiO}_{3}\right.$ or $\left.(\mathrm{Mg}, \mathrm{Fe}) \mathrm{SiO}_{3}\right)$ and olivine (Mg, $\mathrm{Fe})_{2} \mathrm{SiO}_{4}$ (Klein and Hurlbut, 1985; Hamblin, 1992). The main constituents of rhyolite are potassium feldspar $\left(\mathrm{KAlSi}_{3} \mathrm{O}_{8}\right)$ and quartz, while sodium plagioclase $\left(\mathrm{NaAlSi}_{3} \mathrm{O}_{8}\right)$ is a lesser component. As a result of weathering of the calcium plagioclase, pyroxene and olivine typical of basalt, the samples of Group 1 (Mkuze River and associated wetlands and floodplain) contain higher concentrations of calcium and magnesium, than those of the Mbazwane Stream System (Groups 2 and 3).

Group 3 has the lowest concentration of many solutes, and includes the rainwater sample, suggesting that rainwater is the primary source of water for samples in this group and that there is little weathering of rock taking place in the upper regions of the Mbazwane Stream catchment. Once again, water chemistry can be linked to catchment geology in a general way.

Group 6 seems to be a product of weathering inputs and evapotranspiration. Of all groups, samples in Group 6 display the highest concentrations of calcium, chloride, magnesium, sodium and TDS.

Solute concentrations would be expected to rise as a result of the process of evapotranspiration, which dominates the water output component of many wetlands in tropical and subtropical areas - particularly in semi-arid settings. The sequence of groups along axis one of the ordination diagram (Fig. 5), represents a gradient from the most dilute sample groups (Groups $2 \& 3$ of the Mbazwane catchment) to the most concentrated groups (Group 5, between the Mbazwane Stream and Yengweni Drainage Line; and Group 6, the outflow into Lake St Lucia). This is considered to represent evapotranspirational concentration of surface water and groundwater that is likely to be occurring in the Mkuze Wetland System. As such it seems that there is chemical processing of water taking place in the Mkuze Wetland System that may make the wetland an important sink for solutes. A useful way of examining the evaporative concentration in systems such as this is by identifying the solute that is conserved over the entire range of total dissolved solid concentrations (or conductivity in this case) in order to compare the behaviour of other solutes during evapotranspiration.

Sodium has been identified as a conserved solute in some systems and was used as representative of evaporation in the Okavango Delta (McCarthy et al., 1993). However, Figs. 6 a and $\mathrm{b}$ display the more complete conservation of chloride in the Mkuze Wetland System. This is suggested by the steeper slope of chloride with an increase in conductivity (slope $=162$ ) compared to the corresponding slope with sodium (slope $=140$ ). The higher slope for chloride indicates that it remains in solution to a greater extent than sodium over the entire conductivity range. The identification of sodium as the most conserved solute in the Okavango Delta may be due to the predominance of this solute relative to chloride within that system. In a study of the chemical evolution of solute concentrations in continental waters, Eugster and Jones (1979) identified chloride as the conserved solute, as have many others. The high degree of conservation is due to the low anion exchangeability of the ion and the high solubility of its compounds (Eugster and Jones, 1979).

\section{The Mkuze Wetland System as a solute sink}

In order to estimate the contributions of the Mkuze River and the Mbazwane Stream to the combined outflow into Lake St Lucia, it is necessary to estimate the rate of water loss by evaporation from the Mkuze River and Canal. A problem exists in that the Mkuze River divides into two not far downstream of the Lower Mkuze
Bridge (Fig. 1). The amount of water flowing southwards from this confluence along the combined canal was not measured but can be estimated crudely based on differences in chloride concentration. Assuming that chloride is conserved in the event of evaporative water loss and that any loss of water can be attributed solely to evaporation, dividing the average chloride concentration of the canal water by the chloride concentration at the Lower Mkuze Bridge yields a concentration factor of 1.2. Multiplying the canal discharge at Ngwenya Pan by this concentration factor suggests that the discharge of water at the head of the canal is $1.7 \mathrm{~m}^{3} \cdot \mathrm{s}^{-1}$. This means that of the water flowing in the upper Mkuze River $\left(2.4 \mathrm{~m}^{3} \cdot \mathrm{s}^{-1}\right)$, approximately $70 \%$ is flowing down the canal, and the remainder is flowing along the former Mkuze River course. This conforms with the view of Stormanns (1987) that the canal drains off a major proportion of water from the Mkuze River.

Taking the linear distance from the Lower Mkuze Bridge to the confluence of the Mkuze River and Mbazwane Stream System, and assuming evaporation is constant over the linear distance between the two sites, a concentration factor of 1.7 is obtained. Thus, we expect that $1.0 \mathrm{~m}^{3} \cdot \mathrm{s}^{-1}$ flows from the Mkuze River via the canal into the combined flows of the Mkuze-Mbazwane System. By subtracting the value obtained from the discharge of water into Lake St Lucia $\left(3.4 \mathrm{~m}^{3} \cdot \mathrm{s}^{-1}\right)$, the input of water from the Mbazwane catchment is estimated as $2.4 \mathrm{~m}^{3} \cdot \mathrm{s}^{-1}$.

Of the three main sources of water, Group 2 will be ignored in considering solute inputs as the discharge contribution of these groundwater and the reed swamp areas were not quantified and is likely to be low. The two main solute sources to the wetland system are represented by Group 1 samples of the Mkuze catchment, and the samples of Group 3 collected in the Mbazwane catchment. Multiplying Group 1 mean solute concentrations by the estimated Mkuze discharge of $1.0 \mathrm{~m}^{3} \cdot \mathrm{s}^{-1}$ and the Group 3 mean solute concentrations by $2.4 \mathrm{~m}^{3} \cdot \mathrm{s}^{-1}$ draining from the Mbazwane catchment, it is possible to crudely estimate solute fluxes $\left(\mathrm{g} \cdot \mathrm{s}^{-1}\right)$ in the individual and combined streams (Table 6). This ignores evapotranspiration and the possibility of additional inflows between the confluence of the Mbazwane Stream and the Mkuze River canal, and the point of outflow into Lake St Lucia. These estimated outflow fluxes are compared to actual outflow solute fluxes, which are the product of discharge at the outflow $\left(3.4 \mathrm{~m}^{3} \cdot \mathrm{s}^{-1}\right)$ and the mean solute concentrations at that site. The ratio of the actual outflow values to the estimated outflow values indicates the extent to which solutes have been concentrated or diluted within the swamp system.

Chloride increases by a factor of 4.51 , magnesium by a factor of 3.57 , sodium by 3.52 and TDS by 3.50 . The fact that most solute concentrations at the outflow are higher than the combined inflows, suggests that there is substantial water loss by evapotranspiration within the wetland ecosystem. An alternative explanation could be that the wetland and local catchment are a substantial source of solutes. However, it is unlikely that large amounts of chloride or sodium would be retained in the system due to the highly soluble nature of their compounds. As a result, chloride and sodium are widely recognised as conserved solutes during evaporation and/or transpiration of surface waters (Eugster and Jones, 1979; McCarthy et al., 1993), and their increased concentration in the outflow of the Mkuze River into Lake St Lucia fits this general model of chemical evolution. Our view is that it is the primary factor in the Mkuze Wetland System.

Multiplying the estimated outflow solute values by 4.51 assumes that all ions are conserved in the same way as chloride, providing an estimate of the amount of solute lost or gained in the swamp (Table 7). Each of the solutes entering the system appears to be accumulating within the Mkuze Wetland System relative to chloride, 


\begin{tabular}{|c|c|c|c|c|c|}
\hline \multicolumn{6}{|c|}{$\begin{array}{c}\text { TABLE } 6 \\
\begin{array}{c}\text { Estimated solute inputs to the Mkuze Wetland System from the Mkuze and } \\
\text { Mbazwane Catchments }\end{array}\end{array}$} \\
\hline Solute ion & $\begin{array}{c}\text { Mkuze } \\
\left(\mathrm{g} \cdot \mathbf{s}^{-1}\right)\end{array}$ & $\begin{array}{c}\text { Mbazwane } \\
\left(\mathbf{g} \cdot \mathbf{s}^{-1}\right)\end{array}$ & $\begin{array}{l}\text { Estimated } \\
\text { outflow } \\
\left(\mathbf{g} \cdot \mathbf{s}^{-1}\right)\end{array}$ & $\begin{array}{l}\text { Actual } \\
\text { outflow } \\
\text { values } \\
\left(\mathbf{g} \cdot \mathbf{s}^{-1}\right)\end{array}$ & $\begin{array}{c}\text { Ratio } \\
\text { actual } \\
\text { outflow: } \\
\text { estimated } \\
\text { outflow }\end{array}$ \\
\hline Calcium $\left(\mathrm{Ca}^{2+}\right)$ & 34.5 & 25.6 & 60.0 & 127.8 & 2.1 \\
\hline Chloride $\left(\mathrm{Cl}^{-}\right)$ & 91.7 & 81.3 & 173.0 & 781.1 & 4.5 \\
\hline Magnesium $\left(\mathrm{Mg}^{2+}\right)$ & 31.9 & 11.9 & 43.8 & 156.2 & 3.6 \\
\hline Potassium $\left(\mathrm{K}^{+}\right)$ & 5.5 & 6.0 & 11.5 & 16.4 & 1.4 \\
\hline Silicon $(\mathrm{Si})$ & 6.8 & 22.9 & 29.7 & 27.4 & 0.9 \\
\hline Sodium $\left(\mathrm{Na}^{+}\right)$ & 102.2 & 79.9 & 182.1 & 640.1 & 3.5 \\
\hline Total dissolved salts (TDS) & 272.7 & 228.0 & 500.7 & 1750.2 & 3.5 \\
\hline
\end{tabular}

indicating that the system is a sink to differing degrees for all of the solutes examined in this study. The least conserved element is silicon, which is likely to be accumulating in large quantities within the Mkuze Wetland System, whereas magnesium, sodium and TDS mimic the conserved status of chloride most closely. Potassium and calcium are intermediate.

The processes by which silicon is lost as silica $\left(\mathrm{SiO}_{2}\right)$, are likely to vary with local conditions and probably include loss by sorption or precipitation as a consequence of evaporation and/or transpiration (Eugster and Jones, 1979), or possibly uptake by plants and incorporation into plant tissue as silica bodies ("phytoliths"). Although it is expected that magnesium would imitate the behaviour of calcium, as both are members of the alkaline earth metals, Eugster and Jones (1979) note that at high chloride concentrations, the magnesium ion behaves as a conserved solute. Sodium ions are mostly conserved in a similar way to the Okavango Delta (Ellery et al., 1998) and about $50 \%$ of calcium entering the swamp is lost within the wetland. The majority of calcium compounds are relatively insoluble, and it is likely that they precipitate out of solution as solute concentration increases due to evapotranspiration.

Iron concentrations have been measured as part of this study, but it became clear during sample analysis that iron chemistry in a wetland system such as this is complex. Acidification of samples (addition of nitric acid to $\mathrm{pH}=2$ ) increased iron concentrations in water samples by up to two orders of magnitude. This was probably due to release of iron into solution as a result of breaking down colloidal iron complexes. However, the presence of iron is clearly visible in the upper reaches of the Mbazwane Stream and Mkuze River, as red iron-rich accumulations. Our view is that the Mkuze Wetland System is also an important sink for iron.

The retention of solutes within the Mkuze Wetland System is likely to have been taking place for a considerable length of time, and it is of interest to consider the importance of such accumulations for the system as a whole. If the accumulations were taking place in the surface waters of the system it would lead to the development of locally saline surface waters - such as the island pans that have been described in the Okavango Delta (McCarthy and Metcalfe, 1990). Of the surface water pans that were sampled in this study, none were particularly saline (the highest conductivity in a surface pan was $\left.1.395 \mathrm{mS} \cdot \mathrm{cm}^{-1}\right)$. The general elevation of the groundwater table relative to surface waters in the Mkuze Swamp suggests that there is very little recharge of groundwater from surface waters. It seems that transpiration by emergent plants in the Mkuze Floodplain is a likely mechanism of solute accumulation, and that many solutes are precipitating out of solution in floodplain soils. The mechanism described in the Okavango Delta for silica in particular is that floodplain vegetation draws surface water into the root zone, where water is taken up and solutes are excluded. As transpiration continues, the concentration of solutes in the soil increases to the point where they saturate out of solution, maintaining low solute concentrations in the surface waters (McCarthy and Ellery, 1995). Thus, silica precipitation occurs in floodplain soils as a consequence of vegetation processes. It has also been demonstrated that in regions of groundwater recharge, calcium and magnesium precipitate out of solution in island margins in the Okavango Delta as a consequence of transpiration by trees in riparian forests (Ellery et al., 1993; McCarthy et al., 1993).

It is possible that vegetation processes in the wetland margins of the Mkuze Wetland, particularly in areas of high transpiration rates by broad-leaved evergreen trees, may focus solutes locally in the soil and groundwater. Ongoing research will attempt to reveal whether or not this is taking place. If so, it is likely to strongly affect both vegetation distribution in its effect on soil chemistry and physics, and also local topography in that local relief may be modified. As such, vegetation may exert strong feedback effects on environmental gradients within the Muse system.

A further possible sink for solutes is peat, which may adsorb cations. Microbial activity within peat deposits may result in the immobilisation of solutes in a concentrated form (McCarthy et al., 1989). Once again, this is the subject of ongoing research.

This study highlights the importance of the Mkuze Wetland System as a sink for solutes, and activities that impact negatively on this wetland would probably lead to increased solute inputs into Lake St Lucia. If South Africa is to uphold its responsibility in terms of international conventions and treaties, such as the Ramsar Convention, then conservation and/or wise use of this wetland system needs to be promoted. In particular, activities such as the construction of the Mpempe and Tshanetshe Canals need to be considered carefully. The canal was designed to increase the supply of freshwater to Lake St Lucia, but it may have less than the desired effect as the canal bypasses the wetlands that perform a vital role in water quality enhancement. Similarly, it may be necessary for land-use practices that reduce transpirational water loss from the system - such as the clearance of riparian forests - to be curtailed. 


\begin{tabular}{|c|c|c|c|c|}
\hline \multicolumn{5}{|c|}{$\begin{array}{l}\text { TABLE } 7 \\
\text { Estimated retention of solutes within the Mkuze Wetland System based } \\
\text { on the difference between expected and measured fluxes at the outflow } \\
\text { into Lake St Lucia }\end{array}$} \\
\hline Solute ion & $\begin{array}{l}\text { Estimated } \\
\text { outflow } \\
\text { x } 4.51\left(g \cdot \mathrm{s}^{-1}\right)\end{array}$ & $\begin{array}{l}\text { Actual } \\
\text { outflow } \\
\text { values }\left(g \cdot \mathbf{s}^{-1}\right)\end{array}$ & $\begin{array}{l}\text { Loss }(+) \text { or } \\
\text { gain }(-) \text { at } \\
\text { outflow }\left(\mathbf{g} \cdot \mathbf{s}^{-1}\right)\end{array}$ & $\begin{array}{l}\text { Percentage of } \\
\text { estimated out- } \\
\text { flow } \times 4.51(\%)\end{array}$ \\
\hline Calcium $\left(\mathrm{Ca}^{2+}\right)$ & 271.0 & 127.8 & 143.3 & 52.9 \\
\hline Chloride $\left(\mathrm{Cl}^{-}\right)$ & 781.1 & 781.1 & 0.0 & 0.0 \\
\hline Magnesium $\left(\mathrm{Mg}^{2+}\right)$ & 197.7 & 156.2 & 41.5 & 21.0 \\
\hline Potassium $\left(\mathrm{K}^{+}\right)$ & 51.8 & 16.4 & 35.4 & 68.4 \\
\hline Silicon $\left(\mathrm{Si}^{4+}\right)$ & 134.1 & 27.4 & 106.7 & 79.6 \\
\hline Sodium $\left(\mathrm{Na}^{+}\right)$ & 822.0 & 640.1 & 182.0 & 22.1 \\
\hline Total dissolved salts (TDS) & 2260.5 & 1750.2 & 510.3 & 22.6 \\
\hline Iron & & & & High \\
\hline
\end{tabular}

\section{Conclusion}

Although the mass-balance approach generally requires data collected over a long period of time, the use of a single sampling period of one week is considered to be valuable in terms of identifying that this system may constitute an important solute sink. This is likely to be particularly true at low flows when residence time is long. At high flows, water would move more quickly through the wetland with a consequent lowering of residence time, allowing fewer interactions with the soil and plants of the system, probably decreasing the capacity of the wetland to act as a solute sink. Measurement of solute budgets during low flows - as was done in this study - probably reflects the normal solute retention capacity of the Mkuze Wetland System.

The high rate of solute accumulation in the Mkuze Wetland System could conceivably have significant impacts on the system as a whole in relation to vegetation distribution and local topography - as is the case in the Okavango Delta. The extent of solute accumulation in the Okavango Delta has been largely viewed as a consequence of its climatic setting - a large wetland system in a semi-arid environment where potential evapotranspiration is greater than rainfall in every month of the year (McCarthy and Ellery, 1998). However, the predominance of transpiration over evaporation in wetland systems may make these processes far more widespread than was previously considered to be the case (McCarthy and Ellery, 1995). Furthermore, spatial heterogeneity in transpiration rates per unit area may also contribute to localised solute precipitation in wetland soils (Ellery et al., 1998). Continued research aims to document and explain the mechanisms of solute removal from source waters in the Mkuze Wetland System in particular, and hopefully, shed light on those environmental factors governing solute precipitation in wetlands in general.

\section{Acknowledgements}

The comment of two anonymous referees, which helped to improve this paper, are acknowledged. The National Research Foundation generously funded this research, and the CSIR financially supported one of the authors (K.Barnes). Annika Dahlberg and Ashleigh Schoultz assisted in the field.

\section{References}

BEGG G (1989) The Wetlands of Natal (Part 3). The Location, Status and Function of the Priority Wetlands of Natal. Natal Town and Regional Planning Commission Report 73.

COWAN GI (1995) South Africa and the Ramsar Convention. In: Cowan GI (ed.) Wetlands of South Africa. Department of Environmental Affairs and Tourism, Pretoria.

COWARDIN LM, CARTER V, GOLET FC and LAROE ET (1979) Classification of Wetlands and Deepwater Habitats of the United States. US Department of Interior, Fish and Wildlife Services. Report FWS/UBS 79-31, Washington, DC.

ELLERY WN, ELLERY K and MCCARTHY TS (1993) Plant distribution in islands of the Okavango Delta, Botswana: Determinants and feedback interactions. Afr. J. Ecol. 31 118-134.

ELLERY WN, McCARTHY TS and DANGERFIELD JM (1998) Biotic factors in mima mound development: Evidence from the floodplains of the Okavango Delta, Botswana. Int. J. Ecol. Environ. Sci. (24) 293313.

EUGSTER HP and JONES BF (1979) Behaviour of major solutes during closed-basin brine evolution. Am. J. Sci. 279 609-631.

FISCHER D (2000) The Retention of Metals in a Wetland Peat Deposit, Mkuze Wetland System, Northern KwaZulu-Natal. Honours Thesis, Univ. of Natal, Durban.

GIESKE A (1996) Modelling surface outflow from the Okavango Delta. Botswana Notes Rec. 28 165-192.

GOODMAN PS (1987) Mkuze floodplain and swamps - Wetland management case study. Afr. Wildl. 41 1-5.

GORDON ND, MCMAHON TA and FINLAYSON BL (1992) Stream Hydrology: An Introduction for Ecologists. John Wiley and Sons, Chichester. 526 pp.

GRANGER E, BREDENKAMP G and VAN ROOYEN N (1996) Coastal Bushveld-Grassland. In: Low AB and Rebelo AG (eds.) Vegetation of South Africa, Lesotho and Swaziland. Department of Environmental Affairs and Tourism, Pretoria.

HAMBLIN WK (1992) Earth's Dynamic Systems (6th edn.) Macmillan Publishing Company, New York. 674 pp.

HUTCHINSON IPG and PITMAN WV (1973) Climatology and Hydrology of the St Lucia Lake System. St Lucia Lake Research Report. 1 Natal Provincial Aministration.

KLEIN C and HURLBUT CS (1985) Manual of Mineralogy (20th edn.) John Wiley and Sons, U.S.A. 596 pp.

KOTZE DC and BREEN CM (1994) Agricultural Land-Use Impacts on Wetland Functional Values. WRC Report No 501/3/94.

MACKAY E (2000) Millennium Wetland Event. Quebec, Canada, August 2000.

MARDIA KV, KENT JT and BIBBY JM (1979) Multivariate Analysis. Academic Press, USA. 518 pp. 
MAUD RR (1980) The climate and geology of Maputaland. In: Bruton MN and Cooper KH (eds.) Studies on the Ecology of Maputaland. Rhodes Univ. and the Natal Branch of the Wildlife Society of South Africa.

MCCARTHY TS and ELLERY WN (1995) Sedimentation on the distal reaches of the Okavango Fan, Botswana, and its bearing on calcrete and silcrete (Ganister) formation. J. Sediment. Res. A65 (1) 77-90.

MCCARTHY TS and ELLERY WN (1998) The Okavango Delta. Trans. Roy. Soc. S. Afr. $\mathbf{5 3}$ (2) 157-182.

MCCARTHY TS, ELLERY WN and ELLERY K (1993) Vegetationinduced, subsurface precipitation of carbonate as an aggradational process in the permanent swamps of the Okavango (delta) fan, Botswana. Chem. Geol. 107 111-131.

MCCARTHY TS and HANCOX PJ (2000) Wetlands. In: Partridge TC and Maud RR (eds.) The Cenozoic of Southern Africa. Oxford Univ. Press. 218-234.

MCCARTHY TS, MCIVER JR, CAIRNCROSS B, ELLERY WN and ELLERY K (1989) The inorganic chemistry of peat from the Maunachira channel-swamp system, Okavango Delta, Botswana. Geochim. Cosmochim. Acta 53 1077-1089.

MCCARTHY TS and METCALFE J (1990) Chemical sedimentation in the Okavango Delta, Botswana. Chem. Geol. 89 157-178.

MITSCH WJ and GOSSELINK JG (1993) Wetlands. (2 ${ }^{\text {nd }}$ edn.) Van Nostrand Reinhold, New York. 722 pp.

MOORE PD and BELLAMY DJ ( 1974) Peatlands. Springer-Verlag, New York. 221 pp.

REPUBLIC OF SOUTH AFRICA GOVERNMENT GAZETTE (1999) World Heritage Convention Act. 414 (20717).
REPUBLIC OF SOUTH AFRICA GOVERNMENT GAZETTE (2000) World Heritage Convention Act, No. 21304. Regulation gazette. 420 (6834).

ROGERS KH (1997) Freshwater wetlands. In: Cowling RM, Richardson DM and Pierce SM (eds.) Vegetation of Southern Africa. Cambridge Univ. Press, Cambridge.

ROGERSFEJ, ROGERS KH and BUZERJS (1985) Wetland for Wastewater Treatment with Special Reference to Municipal Wastewaters. Olifants Working Group, Department of Botany, Univ. of the Witwatersrand. Witwatersrand Univ. Press, Johannesburg.

SKOOG DA, WEST OM and HOLLER FJ (1996) Fundamentals of Analytical Chemistry ( $7^{\text {th }}$ edn.) Saunders College Publishing, Philadelphia. $971 \mathrm{pp}$.

SPSS for Windows (1995) Version 6.1.3.

STORMANNS CH (1987) An Inventory and Assessment of the Conservation Value of the Greater Mkuze Wetland System. Investigational Report No 36. Ecosystem Res. Natl. Conserv. Res. Section, CSIR.

TAYLOR RH (1993) History and management options. In: Taylor RH (ed.) Proc. of the Workshop on Water Requirements for Lake St Lucia. Held at Fanies Island, 12 \& 13 May 1992. Department of Environment Affairs, Pretoria.

WATKEYS MK, MASON TR and GOODMAN PS (1993) The role of geology in the development of Maputaland, South Africa. J. Afr. Earth Sci. 16 (1) 1-16.

WILSON BH and DINCER T (1976) An introduction to the hydrology and hydrography of the Okavango Delta. Proc. Symp. On the Okavango Delta and Its Future Utilization. Botswana Soc., Gaborone. 21-28. 